Itinéraires Itinéraires

Littérature, textes, cultures

\title{
Voicing the Vagabonde: Revindications and (Mis)appropriations in Contemporary Francophone Literature
}

La voix de la vagabonde: revendications et (més)appropriations dans la littérature française contemporaine

\section{Dúnlaith Bird}

\section{OpenEdition}

\section{Journals}

\section{Electronic version}

URL: http://journals.openedition.org/itineraires/3727

DOI: 10.4000/itineraires.3727

ISSN: 2427-920X

\section{Publisher}

Pléiade

\section{Electronic reference}

Dúnlaith Bird, « Voicing the Vagabonde: Revindications and (Mis)appropriations in Contemporary

Francophone Literature », Itinéraires [Online], 2017-1 | 2018, Online since 15 February 2018, connection on 30 April 2019. URL : http://journals.openedition.org/itineraires/3727 ; DOI : 10.4000/ itineraires.3727

This text was automatically generated on 30 April 2019.

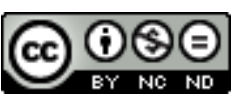

Itinéraires est mis à disposition selon les termes de la licence Creative Commons Attribution - Pas d'Utilisation Commerciale - Pas de Modification 4.0 International 


\section{Voicing the Vagabonde: Revindications and (Mis)appropriations in Contemporary Francophone Literature}

La voix de la vagabonde : revendications et (més)appropriations dans la littérature française contemporaine

Dúnlaith Bird

\section{Introduction}

1 As the eminent sociologist and historian Jean-François Wagniart notes in Le Vagabond à la fin du XIX siècle, "Vagabonds [...] leave little trace, and never directly. They do not write, and speak little"1 (Wagniart 1999: 9). This is particularly true of the female vagabond, almost entirely effaced from historical accounts, and indeed from much modern critical theory. From Karl Marx to Alexandre Vexliard to Wagniart, the female vagabond or vagabonde, on the rare occasions she appears in vagabondage studies, is a fleeting and muted figure. This article explores how two contemporary Francophone women travel writers and novelists have sought to rehabilitate the vagabonde, to appropriate her image as a feminist forbearer or to harness her illicit appeal.

2 How does one write the stories, much less the biographies, of women who leave no tracks? How does one recuperate, without (mis)appropriating? Fiction and travel writing appear to offer two potential means of restituting the figure of the vagabonde. In Colette's semi-autobiographical novel, La Vagabonde (1910), the protagonist, Renée, defiantly identifies as a vagabonde, aligning with the prostitutes of Montmartre as part of "the race that does not yield"2 (Colette 1910: 125). Yet this identification, though arguably allowing 
one of the richer explorations of the vagabonde and of vagabondage in the twentieth century, is problematic. Not only does Colette's novel perpetuate the historical conflation of the female vagabond and the prostitute, the fictional strategies employed by the author allow her to both explore and disavow her own vagabondage.

Colette's contemporary, the Swiss traveller, Isabelle Eberhardt (1877-1904), is more explicit in her espousal of vagabondage as a process of physical, textual, and sexual exploration: "vagabondage is emancipation"3 (Eberhardt 1902b: 27). However her desire to construct a network of exceptional and marginalised women stretching across Algeria and Tunisia often leads to a silencing of the stories of native women, whose narratives of vagabondage are mobilised uniquely to legitimise Eberhardt's own. In doing so, Eberhardt reproduces the historical modes of repression her texts ostensibly seek to circumvent. The article will argue that attempts by Colette and Eberhardt to voice the vagabonde risk reducing her to a mere cipher, and covering over the few traces of the "real" vagabondes found in historical texts and legal documents.

\section{Vagabondage: Definitions and Historical Precedents}

4 Vagabondage, as defined in Travelling in Different Skins (2012), can be seen as "the search for identity through motion," a physical, sexual, and textual elaboration without a fixed itinerary (Bird 2012: 3). Vagabondage emerges as a paradigm in European women's travel writing from the nineteenth century onwards, inspired by historical vagabondage and offering a new means of representing mobility and gender (30-65). ${ }^{4}$ As both Sidonie Smith and bell hooks have noted, however, any paradigm which enshrines female mobility as the acme of liberty and self-expression ignores centuries of forced migration and slavery (Smith 2001, hooks 2008). Travel, and travel writing, can also be seen as limited to a relative economic and social elite, even into the twenty-first century (Smith 2001). Though this is less true for the vagabondage paradigm, predicated as it is on social marginalisation and exclusion, issues of access and privilege remain. Given the hierarchy in European civilisations of the written word over the oral account, its greater credibility and legal weight (Ong 2012: 2), the female vagabond is unfailingly categorised as inferior by dint of gender, economic status, and access to the written word.

5 Vagabondage shares common elements with other peripatetic paradigms enjoying an academic resurgence, including dromomania, also known as the travelling fugue, and flânerie. The nineteenth-century medicalisation of dromomania (the compulsive need to travel), by Charcot and Tissie, was mirrored in certain respects by developments in the treatment of vagabonds, as explored in André Gueslin's recent study (Gueslin 2013). Psychiatric and psychological explanations were increasingly privileged in both cases, though vagabondage, unlike dromomania, remained a criminal act into the twentieth century (Hacking 1998). The two volumes of Le Vagabond en Occident supply a fascinating historical overview of the figure from the Middle Ages to the present day, including the shift from criminalisation to pathologisation in the nineteenth century (Desvois and Munro-Landi 2012).

6 Vagabondage can also be distinguished from its close cousin, flânerie, though the paradigms again share common traits. The flâneur and the vagabond have a passion for "the fugitive and the infinite"5 (Baudelaire 2010). Yet where the flâneur is the archetypal city dweller, the vagabond inhabits liminal spaces on the edge of sedentary societies. The 
original flâneur is described by Baudelaire as urban royalty, observing the crowds with an artist's eye: "a prince who everywhere enjoys his incognitio"6 (Baudelaire 2010), whereas the vagabond is marked out by the law for punishment. However contemporary studies of flânerie suggest increasing similarities with modern vagabondage studies. Federico Castigliano's experimental 2016 text on flânerie can be read sequentially or freely, allowing the reader to become lost in the flow of fiction and non-fiction chapters just as the narrator loses himself in the streets of Paris. This textual innovation resonates with explorations of vagabondage by writers from Colette and Rachilde to Karen Guillorel. Meanwhile, Lauren Elkin's text asserts the existence of the flâneuse and of female creativity in a paradigm predicated on their objectification (Elkin 2016), just as contemporary writers continue to reclaim the vagabonde.

7 From the fourteenth century onwards, the vagabond is written on and written against, at the mercy of legal documents and royal proclamations (Geremek [1976] 2006). Vagabonds exist outside established social structures: "His Majesty declares vagabonds and vagrants those who have neither profession, nor trade, nor fixed abode, nor means of subsistence" 7 (France 1718: Article III). As the proclamation demonstrates, vagabonds are framed, linguistically and legally, in negative terms, and their crime is defined by their deviation from social norms. In the Ordonnance $d u$ Roy of November 1718, vagabonds and vagrants are accused of public unrest and armed violence: "they continually commit acts of public disorder and violence which invoke at once the authority of His Majesty, the safety of the public, and the peace of individual citizens"8 (France 1718). As usual, the crimes attributed to vagabonds are met with particularly energetic official reprisals: "to which it is necessary to respond with all the severity such a grave situation demands"9 (France 1718).

8 The vagabond poses an unacceptable threat to settled communities, and even to the authority of the king. The proclamation therefore mandates the immediate arrest and imprisonment of all vagabonds and vagrants, in the closest possible royal prison (France 1718: Article 1). Containment is swiftly followed by categorization: all of the vagabonds captured are to be entered in a registry, so that they can be shipped to the colonies if strong enough to serve, and punished in other ways if not. As is common in official state documents of the XVII-XIX centuries, the vagabond is repurposed to serve the state, recuperated for economic gain or definitively excluded from society. The language deployed against the vagabond is as chilling as it is efficient: "And see to the punishment of the others"10 (Article II).

The punishment is even more severe when the proclamation is concerned with sexual mores, and with the vagabonde. In the Ordonnance $d u$ Roy, Concernant les Mandiants, Vagabonds et Gens sans aveu, of March 1720, vagabonds are seen begging "insolently and scandalously, more from debauchery than from necessity"11 (France 1720). This text specifically concerns vagabonds and vagabondes: "of both sexes"12 (Article 1). The spectre of sexual excess is invariably present in official references to the vagabonde, generally conflated with the prostitute as Wagniart notes (1999: 40). Persistent female vagabonds, like prostitutes and other "lost women," were imprisoned in the Salpêtrière to await reform or death. Given the historical precedent, it is perhaps unsurprising that even in the twentieth century French women writers including Colette and Eberhardt explore literary strategies in order to circumvent the more dangerous ramifications of labelling oneself a vagabonde. 


\section{Colette: La Vagabonde}

10 Vagabondage is a process of self-fashioning rooted in the physical world and founded on autobiographical events, in which the lines of the pacte autobiographique proposed by Philippe Lejeune (1975), and in the autofiction of Serge Doubrovsky, are deliberately blurred. As Stéphanie Michineau notes in her work on Colette, "autofiction" is used to denote a text both lesser and greater than an autobiography; lesser, because autobiographies are conventionally reserved for prominent figures in history, greater, because it furnishes life with art (Michineau 2008: 16). Michineau contends that writing autobiography is particularly complex for women constrained by the social norms of Colette's epoch, and that autofiction is a potentially fruitful strategy, since it offers just enough plausible deniability: "This hypothesis is corroborated by the fact that autofiction is used by 'exceptional persons' or for the discussion of exceptional subjects"13 (19). Although I would agree with Michineau that the dimension of gender is key to Colette's strategy, I would argue that the connotations of vagabondage add another layer to her work.

\section{The Woman in the Mirror}

11 From the beginning of the Claudine series (1900), Colette's fiction closely traces her own life and experiences. Yet in La Vagabonde (1910), the light, romantic tone of the "Claudine" series is abandoned in favour of a darker tale of self-fashioning, suffering, and desire. The novel draws heavily on Colette's theatrical experiences as an actress from 1906, following the breakdown of her relationship with Henri Gauthier-Villars. For Colette to openly adopt the term vagabonde on the title page of her autobiographical novel is a daring act. The Flammarion edition of Colette's letters to friends during her theatre years, Lettres de la vagabonde (1961) indicates how closely Colette remained tied to her fictional creation. This may explain why Colette distances herself from her character in La Vagabonde in small yet strategic details: Rénée's ex-husband is Adolphe Taillandy, a pastel artist who paints the same velvety, soft-focus portrait of the same woman for twenty years (Colette 1910: 29), whereas Henri Gauthier-Villars signed Colette's early memories of her schooldays with his own name. Both men blur the image of their wives, appropriating their identities for financial ends: both women eventually choose creative and marital emancipation, though at a cost.

Colette walks a fine line with the character of Rénee, realistic enough to titillate her readers yet fictional enough to avoid social or legal sanction. Through Rénée, Colette strategically expresses her own desire for sexual and artistic exploration. A triple staging occurs: Colette's theatrical performances are repositioned as Rénée's, then represented by Colette the writer. A refracted, at times fragmented, persona emerges, as it does in Eberhardt's vagabondage travel writing. The novel is filled with mirrors, which periodically threaten to reveal Rénée's true face: "I will end up alone with myself"14 (Colette 1910: 1). Every time she thinks the word "me," Rénée's eye is drawn to the mirror: "Me... As I thought that word, I looked inadvertently at the mirror"15 (4). As Michineau notes, "Claudine, Annie, Rénée and others represent, in many respects, doubles of the author"16 (Michineau 2008: 18). If the mirror is the reflection of consciousness, the moment when the child first sees and conceives of itself as a whole, 
then Rénée's relationship with her reflection denotes not just her fractured sense of self, but her apprehension of another self beyond the mirror. For Colette, vagabondage is both an act of revindication and of destruction, the notion of a fixed identity abandoned in favour of a painful "becoming."

In the opening scene of the novel, Rénée examines the scratches in the walls of the dressing room, where endless, faceless actresses have attempted without success to claw their own initials (Colette 1910: 2). Colette returns periodically to this image of the caged woman. Rénée, herself a frustrated writer, describes writing as "unconscious scribbling"17 (14). Colette appears to suggest that women who do not write themselves into new identities will struggle to leave their mark, their names subsumed into other people's stories. Rénée struggles with her writer's block just as she struggles with her reflection, "this impenetrable mirror I bang my head against"18 (16). The image is not simply one of creative frustration, however. Rather than banging her head against a brick wall, Rénée senses that the solution to her problems as a woman and a writer lie somewhere in the ground between fiction and reality, in the space just beyond the mirror.

Rénée is half-aware of her own status as a fictional protagonist, a more brightly-coloured version of the author herself. She is surprised each time by the garishness of her own face: "covered in violet rouge, eyes ringed with a halo of greasy blue which is beginning to melt"19 (Colette 1910: 4). Yet she refers to her reflection as "the painted counsellor who spies on me from the other side of the mirror"20 (2). Colette the author watches her fictional counterpart, guiding and manipulating her, as reality and fiction become entangled. Rénée imagines her whole reflection melting into a coloured smear on the glass, with nothing remaining of reality, and nothing remaining of her "self" save another ellipsis: "Moi..." (4). The repeated ellipses reinforce the sense that there is something unfinished in Rénée, a constant movement towards becoming something else, elsewhere: she is the vagabonde incarnate.

\section{Vagabondes and Prostitutes}

One of the elements uniting the contemporary and the historical vagabonde is that both are condemned for earning a living in ways deemed dubious or unacceptable by society: writing and prostitution. As Rénée says without shame, "I make my living, that is a fact" (Colette 1910: 34). Financial independence on a public stage is a tricky prospect for a woman into the twentieth century, and prostitution and the theatre are strongly linked, as Colette demonstrates with the stream of male admirers who flock to Rénée's shows and to her dressing room. Colette even pokes fun at herself through Rénée's self-portrait as "A woman of letters gone bad"22 (14), playing on the notion that one of the most evocative ways for a woman to go bad, entrenched in the French imagination through royal proclamations, newspaper articles, medical tracts, and fiction, is for her to turn to prostitution.

16 Yet Colette's treatment of prostitution is more ambivalent than it first appears. In a café in Montmartre, Rénée's eye is drawn to a young prostitute who refuses to be pitied, subsisting on pride and rage: "She is ready to insult, to scratch"23 (Colette 1910: 121). The use of the word "griffer" links the prostitute to the earlier scenes of the actresses attempting to scratch their initials on the dressing-room walls, the writer failing to write in her garret, and the vagabond-actress, turning in circles on the provincial circuit (101). These women, frustrated in their self-expression, limited in their economic means, fall 
back on the physical: fingers become claws, as they do violence to themselves or others. As the author-narrator comments, "The species is not uncommon" ${ }^{24}$ (121). The prostitutes in particular are depicted as animalistic, vicious, a species to be observed from a safe distance.

There is a coolness to Rénée's observation, a deliberate distancing despite instances in the text where the lines between the prostitute, the actress, and the vagabonde are blurred. Her grudging admiration for the determination of these women to survive is evident: "they are of the race that does not yield" 25 (Colette 1910: 125). However the language the narrator uses to describe them is that of a scientist categorising a lesser organism: "espèce," "race." Rénée affirms that she instinctively knows a thing or two about such women, when she comes across them in Montmartre: "As though they were giving me a passing lesson, an example against all weakness" 26 (125). Finally the prostitutes are not sister-vagabondes, but cautionary tales of excessive and unchecked female sexuality. They have merit only in their fleeting tutelary value, their own vagabondage reduced to a passing thought in the mind of the main character. The historical trope of the female vagabond, silent, sexual, and sinning, is reproduced even in this fictional reclaiming of the vagabonde.

\section{Eberhardt: Lineage and Legitimacy}

In her travel writing, Isabelle Eberhardt proclaims the pursuit of "vagabondage" to be a fundamental right (Eberhardt 1902b: 27). Her travel writing becomes a manifesto of this creed, a counter-proclamation to the historical Ordonnances $d u$ Roi. Rather than seeking to immobilise and imprison the vagabonde, as in the royal proclamations, her text performatively enacts her liberation: "vagabondage is liberation"27 (Eberhardt 1920b: 27). Colette's insistence on the solitude of the vagabonde as a necessary condition (Colette 1910: 12-13) is echoed in Eberhardt's travel writing: "one is only free as long as one is alone"28 (27). Despite this, however, Eberhardt still seeks tracks to follow in the desert, a lineage of exceptional Algerian vagabondes to replace her rejected European heritage and lend legitimacy and force to her own vagabondage (Bird 2012: 196-98). Legitimacy as a vagabonde, in Eberhardt's construction, is amassed, accumulated over distance and significant encounters, rather than inherited. Eberhardt's headlong flights through the desert are therefore punctuated with meetings with fellow vagabondes, those who have also chosen, or been forced, to live outside the norms of their society.

\section{Meeting the Maraboute}

Eberhardt's meeting with the maraboute (holy woman), Lella Zeyneb, is seen as highly significant by her biographer, Edmonde Charles-Roux, who devotes a chapter to their encounter (Charles-Roux 1995: 429-437). Zeyneb was the daughter of a marabout (holy man), Sidi Mohammed Belkassem. On her father's death, she was designated as his worldly and spiritual heir. Deemed a usurper by her cousin, who saw himself as the rightful heir, Zeyneb was held in her apartments under constant surveillance. As CharlesRoux recounts, Zeyneb (or Zeineb) alerted the officers of the French Arab Bureau, and then used her perfect grasp of the French language to plead her case with the "procureur de la République" (public prosecutor of the Republic) (430). Intriguingly, Zeyneb's mandate for her unconventional life derives in part from her father, and in part from a 
foreign colonial power. Like all vagabondes she is Other, operating outside the conventional bounds of her society, yet her vagabondage is marked by a double authority. Her apparent ability to move between cultures is even more appealing to Eberhardt, a stateless refugee born to Russian parents in Switzerland (Bird 2012: 14). Eberhardt, I would argue, seeks in the alternative authority figure of Zeyneb a legitimation of her own identity as a vagabonde.

Eberhardt notes as significant the fact that the zaouiya (religious school) of Lella Zeyneb is located in El-Hamel: "a poetic name meaning 'The Lost One"”29 (Eberhardt 1902a: 120). It is the perfect place for an erring vagabonde to find one of her tribe. The scene is infused with symbolism as well as contradictions. The school, though lost in the desert, exists in an improbable oasis of green, "fresh and delightful" ${ }^{30}$ (120). Eberhardt's desire for a place that is at once home and escape is mirrored in the location of the school: "in a valley hemmed in on one side and open on the other, towards the oued (watercourse), onto a vast, azure horizon" 31 (120). The school itself is composed of two buildings: "one very white, European in appearance, the other made from very light clay, with occasional narrow openings" ${ }^{32}(120)$. The symbolism is less than subtle: here is a place marked by duality, where the European and the Algerian meet and co-exist. It is difficult to escape the conclusion that in this scene, Eberhardt intends to reconcile the conflicting aspects of her identity through a cathartic meeting of worlds.

Although Eberhardt's travel writing is largely autobiographical, certain events are embroidered to increase the intensity or highlight the importance of the scene. Her detailed description of the location is intended to render it exceptional in the reader's mind, to prepare the ground for the meeting to come: "This place has a special quality, uniquely its own, which resembles neither the Sahara nor the usual landscapes of the High Plains" ${ }^{33}$ (Eberhardt 1902: 121). Eberhardt sees herself as having "penetrated" this world and integrated its value systems, "forever closed to the scrutiny of the tourist, however attentive and intelligent it might be" ${ }^{34}$ (121). Yet the reference to the burnous reminds the reader that for all her claims of belonging, and for all biographer CharlesRoux's defence of her pure intentions (Charles-Roux 1995: 435), Eberhardt arrives under false pretenses, dressed in Arab robes and posing as Sidi Mahmood, the young male Arabic scholar.

22 After the elaborate staging, the meeting with Lella Zeyneb is recounted in less than a page and a half. Zeyneb's defining characteristic for Eberhardt is that she is a traveller, her face tanned and wrinkled, "because she travels a lot in the region" 35 (Eberhardt 1902: 122). Eberhardt, the illegitimate daughter of Alexander Trophimowsky, firmly establishes the credentials and legitimacy of Zeyneb first as a woman and then as her father's spiritual heir: "It is Lella Zeyneb, the daughter and the heir of Sidi Mohammed Belkassem"36 (122). Eberhardt makes it clear that she identifies with Zeyneb. Like Eberhardt's father, who encouraged her cross-dressing and took charge of her wideranging and esoteric education (Bird 2012: 136-7), Sidi Mohammed Belkassem "was preparing for his daughter a very different role than that which usually falls to the Arab woman" ${ }^{37}$ (122).

23 Following her legal battles, Zeyneb directs both the religious school and its holy orders. Above all, Zeyneb's school offers sanctuary to the dispossessed and the vagrant, to those existing on the margins of society (Eberhardt 1902: 122). Strikingly, however, we hear almost nothing directly from Zeyneb herself, despite Eberhardt's positioning of the maraboute as a kind of Mother of All Vagabonds. This quasi-effacement of the woman she 
has come to meet is glossed by Eberhardt as the result of illness; Zeyneb is suffering from painful throat problems (122). Rather than hearing Zeyneb's account of her own life, the reader is assured of her interest in and support of Eberhardt's wanderings: "My circumstances, my way of life and my history are extremely interesting to the maraboute. When she has heard everything, she applauds me and assures me of her eternal friendship" ${ }^{38}$ (122). Zeyneb's function within Eberhardt's travel writing is to listen, and to approve of Eberhardt's vagabondage.

Largely silenced in order to better perform her role, the reader is given a direct quote from Lella Zeyneb only once. Calling Eberhardt "my daughter," she bemoans the fact that she has given everything to doing good in the name of God, and remains unrecognised, even hated for it (Eberhardt 1902: 122). She continues, "and yet I have given up everything: I never married, I have no family, no joy..." ${ }^{39}$ In the official proclamations discussed above the vagabond is defined in negative terms, having no work and no fixed abode. In her manifesto on vagabondage, Eberhardt seeks to reclaim this negative framing, this linguistic dispossession, as a form of liberation (VB 27-8). Yet Lella, in the single sentence she is allowed to say, presents the human cost of vagabondage as a litany of loss. As Eberhardt notes, this suffering has probably been hidden for years, only brought to light "in the presence of another woman whose destiny is also very far from the ordinary" ${ }^{\prime 0}$ (123). Vagabonds, as Wagniart says, speak little (Wagniart 1999: 9), and Eberhardt seems to suggest that it is only in the company of other vagabondes that they can finally express themselves.

Yet this sisterhood of vagabondage is short-lived. The convenient plot device of a hoarse cough cuts off Zeyneb's confidences, allowing Eberhardt to resume control of the narrative. Somewhat prematurely envisaging the maraboute's death, the writer muses that this unique woman deserves further study: "and would deserve, certainly, to be studied in greater depth than I have been able to during a too-fleeting stay at the zaouïy" ${ }^{41}$ (Eberhardt 1902: 123). There is something offhand in the word "certes," as though Eberhardt recognises the significance of Zeyneb's potential memoirs but refuses to let them slow her down: if her stay is fleeting, it is by conscious choice. Zeyneb's voice is a potential inconvenience to Eberhardt, muddying the narrative and offering an alternative protagonist. Instead Eberhardt ventriloquises Zeyneb's voice, marshals Zeyneb's approval, and then abandons her to silence.

\section{Dismissing the Maraboute}

Dismissing the maraboute while conserving the power of her endorsement requires skilful textual manoeuvring on Eberhardt's behalf. Amidst all of her accounts of encounters with exceptional Algerian and Tunisian women, from Mériéma (Eberhardt 1903: 153-55) to "La Révoltée" (The Rebel) (Eberhardt 1904: 270-71), the meeting with Zeyneb stands out. In her comprehensive biography Charles-Roux finds it "extremely strange" that Eberhardt does not insist on the exceptional nature of her stay at the school, as the first European to be welcomed thus. She wonders why Eberhardt does not describe it as a "feat," and suggests this may be because Eberhardt wished to feel at home instead (Charles-Roux 1995: 436). While I would agree that Eberhardt sees the school primarily as a safe space for vagabonds, and thus for herself, I would suggest that Eberhardt deliberately works to diminish the exceptional nature of the scene, both during the meeting with Zeyneb and in the aftermath. Vagabondage is an inherently solitary process of self-fashioning with room 
for a single protagonist. Other vagabondes remain excluded, a source of literary inspiration without apparent agency.

Tellingly, Eberhardt describes her time at the school as a dream, which has now fled: "This seven-day dream has fled, after so many others" ${ }_{42}$ (Eberhardt 1902: 123). She insists again on the dreamlike nature of the encounter: "I am almost at the point of asking myself if it is really true, if all of this fleeting enchantment is not a dream" ${ }^{43}$ (123). She goes on to wonder whether the town of Bou-Saâda, the religious school, and the maraboute herself, are not all products of her own nostalgic imagination (123). The force and sadness of Zeyneb's words are converted into the writer's imaginings, underlining the fact that the fictionalised maraboute only exists for Eberhardt to vindicate her choices and her lifestyle. Her repetition of the word "rapide," used a few lines above to describe her visit to the school, is interesting. Arguably it is not the dream which has fled, but rather Eberhardt herself, who flees other vagabondes even as she seeks them out, who uses the voices of other vagabondes to ventriloquise her own desires, and uses the techniques of fiction in her travel writing to tell the biography of a certain kind of vagabonde. We hear one more echo of the maraboute, apparently not yet dead, and still capable of talking. Eberhardt meets her former guide in Alger, who claims that "the maraboute often speaks of you" ${ }^{44}$ (124). It is possible the maraboute has fond memories of a fellow vagabonde. Yet the only topic she is allowed to speak on, through the pages of Eberhardt's writing, is Eberhardt herself.

\section{Conclusion: A Vagabonde by any other Name?}

The breathless closing paragraphs of Ella Maillart's Oasis interdites (1937) suggest that elements of the vagabondage elaborated by writers, including Colette and Eberhardt, persist well into the twentieth century, though the term vagabonde falls somewhat out of favour. Not only does Maillart's title conserve the illicit charge of vagabondage, like Eberhardt her style of writing mimics her mode of travel: "After so many strange places, Japanese, Chinese, Tibetan, Mongol, I had no sooner touched down on French soil in Marseilles than the airplane with a single thrust was once again in the air" 45 (Maillart 2002: 312). The run-on sentences accelerate the pace of the travelogue, while the succession of commas recalls how Maillart's successive journeys bled into one another across the Asian continent.

More recently, travel writers including Karen Guillorel (2009) have chosen to reanimate the figure of the erring, uncontrollable vagabonde as a potential model for modern women's travel writing. Even in the twenty-first century, the woman traveller, arguably more than her male contemporary, is confronted with the questions of legitimacy and authority in her travelogues; the pacte autobiographique is still fragilised at times. The figure of the vagabonde lends strength to these women's narratives of free and openended movement, allowing them to construct powerful vagabonding identities. In doing so, however, they risk burying, once again, the historically effaced figure of the vagabonde

Can these narratives be retrieved, or are they by their nature irrevocably effaced? Does retrieval inevitably connote recuperation, rewriting, and an even more insidious process of effacement? Can it ever be a reclaiming of devalued modes of travelling, a revindication of different performances of gender, or a retracing of a long-lost female 
lineage? Fiction can reinforce biography, and help to fill the gaps where the stories and the lives of marginalised groups might otherwise be lost. There might even be an enriching of reality, as in Alan Duff's rendering of the celestial bodies that overlook the prosaic violence of the lives of Maori families in the Auckland slums in Once Were Warriors (Duff 1990: 78). Just as Duff's trilogy was contested by certain Maori for stereotyping and excessive violence, for speaking for and on behalf of a community (Martens 2007), so contemporary vagabondes are open to accusations of ventriloquisation of the historical vagabonde. While not wishing to map one debate onto another, such discussions on authoring and authority may be useful for vagabondage studies, in order to avoid reproducing similar hierarchies of agency and representation. As Albéric d'Hardivilliers notes in L'Écriture de l'ailleurs: Petits propos sur la littérature nomade (2009), "literature and travel shape, in everyone, step by step, a densified and enriched reality" 46 (Hardivilliers 2009: 88). In the art of being elsewhere, travel and writing are mutually constitutive, and the paradigm of vagabondage offers new possibilities for understanding the semi-fictional, semi-autobiographical selves elaborated by contemporary women writers.

\section{BIBLIOGRAPHY}

Baudelaire, Charles, 2010, "II - Le Croquis de mœurs," in Le Peintre de la vie moderne, Paris, Fayard.

Bird, Dúnlaith, 2012, Travelling in Different Skins: Gender Identity in European Women's Oriental

Travelogues, 1850-1950, Oxford, Oxford University Press.

Castigliano, Federico, 2016, Flâneur: The Art of Wandering the Streets of Paris, North Charleston, CreateSpace Independent Publishing Platform.

Charles-Roux, Edmonde, 1995, Nomade j'étais : les années africaines d'Isabelle Eberhardt, 1899-1904, Paris, Grasset.

Desvois, Francis, and Munro-Landi, Morag, 2012, Le Vagabond en Occident : sur la route, dans la rue, 2 vol., Paris, L'Harmattan.

Duff, Alan, 1990, Once Were Warriors, Auckland, Tandem Press.

France, 1718, Ordonnance du Roy, Contre les Vagabonds et Gens sans aveu, 10 November 1718, [Online], http://gallica.bnf.fr/ark:/12148/btv1b8607671v, accessed 10 December 2017.

Elkin, Lauren, 2016, Flâneuse: Women Walk the City in Paris, New York, Tokyo, Venice, and London, London, Chatto \& Windus.

France, 1720, Ordonnance du Roy, Concernant les Mandiants, Vagabonds et Gens sans aveu, 10 March 1720, [Online], http://gallica.bnf.fr/ark:/12148/btv1b86083625, accessed 10 December 2017.

Geremek, Bronislaw, [1976] 2006, The Margins of Society in Late Medieval Paris, Cambridge, Cambridge University Press.

Gueslin, André, 2013, D'ailleurs et de nulle part: Mendiants vagabonds, clochards, SDF en France depuis le Moyen Âge, Paris, Fayard. 
Guillorel, Karen, 2009, De l'aventure au voyage intérieure : Paris - Istanbul - Jérusalem, Paris, Presses de la Renaissance.

Hacking, Ian, 1998, Mad Travellers: Reflections on the Reality of Transient Mental Illnesses, Charlottesville and London, University Press of Virginia.

Hardivilliers, Albéric d', 2009, L'Écriture d'ailleurs : petits propos sur la littérature nomade, Paris, Transboréal.

hooks, bell, 2008, Belonging: A Culture of Place, London, Routledge.

Lejeune, Philippe, [1975] 1996, Le Pacte autobiographique, Paris, Seuil.

Maillart, Ella, 2002, Oasis interdites, Paris, Éditions Payot \& Rivages.

Martens, Emiel, 2007, Once Were Warriors: The Aftermath, Amsterdam, Amsterdam University Press. Michineau, Stéphanie, 2008, L'Autofiction dans l'œuvre de Colette, Paris, Publibook.

Ong, Walter, 2012, Orality and Literacy: The Technologizing of the World (30 ${ }^{\text {th }}$ Anniversary Edition), Abingdon, Routledge.

Smith, Sidonie, 2001, Moving Lives: Twentieth-Century Women's Travel Writing, Minneapolis, University of Minnesota Press.

Vexliard, Alexandre, 1956, Introduction à la sociologie du vagabondage, Paris, Librairie Marcel Rivière et Cie.

Wagniart, Jean-François, 1999, Le Vagabond à la fin du XIX siècle, Paris, Belin.

\section{Corpus}

Colette, 1910, La Vagabonde, Paris, Librairie Paul Ollendorff.

Colette, 1961, Lettres de la vagabonde, R. Forbin and C. Pichois (eds.), Paris, Flammarion.

Eberhardt, Isabelle, 1902a, Bou-Saâda, in Écrits sur le sable: Euvres complètes I, M. O. Delacour and J.R. Huleu (eds.), Paris, Grasset, 1988, p. 111-24.

Eberhardt, Isabelle, 1902b, Heures de Tunis, Écrits sur le sable, p. 27-35.

Eberhardt, Isabelle, 1903, Sud oranais $1^{\text {re }}$ partie, Écrits sur le sable, p. 125-222.

Eberhardt, Isabelle, 1904, Sud oranais $2^{e}$ partie, p. 223-300.

\section{NOTES}

1. "Les vagabonds [...] laissent peu de traces et en aucun cas directement. Ils n'écrivent pas et parlent peu." All translations into English are my own.

2. "[...] la race qui ne cède pas."

3. "[...] le vagabondage, c'est l'affranchissement."

4. The term gender is used in this text to refer to interlinking cultural, social, and biological constructs of identity, often focused on a male/female binary. Sexuality here denotes both sexual activity and sexual orientation.

5. "[...] le fugitif et l'infini."

6. "[...] un prince qui jouit partout de son incognitio." 
7. "Déclare Sa Majesté vagabonds et gens sans aveu ceux qui ont ni profession, ni métier, ni domicile certain, ni bien pour subsister."

8. "Ils commettent continuellement des désordres et violences qui intéressent également l'autorité de Sa Majesté, la sûreté publique et le repos des particuliers."

9. “[...] à quoi étant nécessaire de pourvoir avec toute la sevérité que demande l'importance de cet objet."

10. "Et pourvoir à la punition des autres."

11. "[...] avec insolence et scandale, plutôt par libertinage que par nécessité."

12. "[...] de l'un et de l'autre sexe."

13. "Cette hypothèse est corroborée par le fait que l'autofiction est utilisée par des "profils d'exception' ou pour le traitement des sujets d'exception."

14. "[...] je vais me retrouver seule avec moi-même."

15. "Moi... En pensant ce mot-là, j'ai regardé involontairement le miroir."

16. “Claudine, Annie, Rénée et d'autres représentent, à bien des égards, des doubles de l'auteur."

17. "[...] le griffonnage inconscient."

18. "[...] ce miroir infranchissable où je me butte."

19. “[...] masquée de rouge mauve, les yeux cernés d'un halo de bleu gras qui commence à fondre."

20. “[...] la conseillère fardée qui m'épie de l'autre côté du miroir."

21. "Je gagne ma vie, cela est un fait."

22. "Une femme de lettres qui a mal tourné."

23. "Elle est prête à insulter, à griffer."

24. "[L]'espèce n'est pas très rare."

25. "Elles sont de la race qui ne cède pas".

26. "Comme si elles me donnaient un vague enseignement, un exemple contre toute faiblesse..."

27. "Le vagabondage, c'est l'affranchissement."

28. "On n'est libre que tant qu'on est seul."

29. "Nom poétique qui signifie 'l'Égaré'."

30. "Frais et savoureux."

31. "Dans une vallée resserrée d'un côté et ouverte de l'autre, vers l'oued, sur un horizon vaste et azuré."

32. "L'un très blanc, d'aspect européen, et l'autre en tourbe très claire, avec de rares ouvertures étroites."

33. "Ce lieu a un aspect particulier, bien à lui, et qui ne tient ni du Sahara, ni du paysage ordinaire des Hauts-Plateaux."

34. "Ce monde des burnous et des turbans, fermé à jamais à l'observation du touriste, quelque attentive et intelligente qu'elle soit."

35. "Car elle voyage beaucoup dans la région."

36. "C'est Lella Zeyneb, la fille et l'héritière de Sidi Mohammed Belkassem."

37. "Préparait à sa fille un rôle bien différent de celui qui incombe généralement à la femme arabe."

38. "Mon cas, mon genre de vie et mon histoire intéressent vivement la maraboute. Quand elle a tout entendu, elle m'approuve et m'assure de son amitié pour toujours."

39. "Pourtant j'ai renoncé à tout: je ne me suis jamais mariée, je n'ai pas de famille, pas de joie..."

40. "En présence d'une autre femme dont la destinée est aussi très éloignée de l'ordinaire."

41. "[...] et mériterait, certes, d'être étudiée mieux que je n'ai pu le faire pendant un séjour trop rapide à la zaouïya."

42. "Ce rêve de sept jours s'est envolé, après tant d'autres."

43. “J'en suis presque à me demander si c'est bien vrai, si toute cette féerie rapide n'est pas un songe." 
44. "La maraboute parle souvent de vous."

45. "Après tant de lieux étranges, japonais, chinois, tibétains, mongols, à peine ai-je foulé à nouveau le sol de France à Marseille, que d'un seul coup de reins l'avion est de nouveau dans l'air."

46. "La littérature et le voyage dessinent progressivement en chacun une réalité densifiée, enrichie."

\section{ABSTRACTS}

In royal proclamations, legal and medical texts, and even newspapers, the vagabond is seen in France from the sixteenth century onwards as a shadowy figure who, according to sociologist Jean-François Wagniart, does not write and speaks little (Wagniart 1999: 9). This effacement is even more striking in the case of the female vagrant or vagabonde, doubly excluded by virtue of her gender and her sexuality. Historically associated with prostitution, marginalised and officially despised, this article explores the attempts by contemporary Francophone women writers Colette and Isabelle Eberhardt to recuperate the image of the vagabonde in their travel writing and autobiographical fiction, appropriating her image as a feminist forbearer or attempting to harness her illicit appeal. Their texts appear, however, to paradoxically reproduce the modes of repression they seek to circumvent, perpetuating the hierarchy of powerful writer and silenced vagabonde, or the conflation of vagabonde and prostitute. Through close readings of selected texts, this article questions therefore whether it is ever possible to truly voice the vagabonde.

Dans les ordonnances du roi de France à partir du XIve siècle, dans les textes légaux et médicaux, et jusque dans les journaux $\mathrm{du} \mathrm{xx}^{\mathrm{e}}$ siècle, les vagabonds restent des êtres sombres et silencieux. D'après le sociologue Jean-François Wagniart, «ils n'écrivent pas et parlent peu » (Wagniart 1999 : 9). La vagabonde, quant à elle, est encore plus méconnue et plus effacée à cause de son genre et de ses débordements sexuels. Souvent associée à la prostitution, détestée et marginalisée, elle est aussi régulièrement effacée des documents officiels. Or, dans les romans autobiographiques de Colette, comme dans les récits de voyage d'Isabelle Eberhardt, la vagabonde resurgit. Les deux auteurs se revendiquent comme vagabondes. Elles cherchent, à travers leurs œuvres d'autobiographie et d'autofiction, à réhabiliter la vagabonde comme égérie féministe, et cherchent à s'approprier sa sexualité débordante. Paradoxalement, ces tentatives textuelles semblent reproduire les modes de représentation et de répression de la vagabonde qu'elles cherchaient à contourner.

\section{INDEX}

Mots-clés: autofiction, Colette, Eberhardt, genre, récit de voyage, vagabonde, vagabondage Keywords: autofiction, Colette, Eberhardt, gender, travel writing, vagabond, vagabondage 
AUTHOR

DÚNLAITH BIRD

Université Paris 13, Pléiade (EA 7338) 